\title{
POLY(VINYL ALCOHOL): FORMULATION OF A POLYMER INK FOR THE PATTERNING OF SUBSTRATES WITH A DROP-ON-DEMAND INKJET PRINTER
}

\author{
POLI(VINIL ALKOHOL): SESTAVLJANJE POLIMERNEGA ČRNILA \\ ZA TISKANJE PODLAG Z BRIZGALNIM TISKALNIKOM
}

\author{
Pavol Šuly, Petr Krčmár̆, Jan Mašlík, Pavel Urbánek, Ivo Kuřitka \\ Tomas Bata University, Centre of Polymer Systems, Tr. Tomase Bati 5678, 76001 Zlin, Czech Republic \\ suly@ft.utb.cz \\ Prejem rokopisa - received: 2015-07-01; sprejem za objavo - accepted for publication: 2016-01-19
}

doi:10.17222/mit.2015.180

\begin{abstract}
Nowadays, inkjet-printing technology is considered one of the most promising deposition techniques. It allows the highly precise deposition of functional materials to the required place on a substrate and a cost-saving printing process, especially when the drop-on-demand manner is used. Moreover, it represents the perfect technique for the controlled deposition of polymer material, especially for polymer solutions, because of their low viscosity and better process ability. Poly(vinyl alcohol) was chosen because of its versatile application potential; moreover, its compatibility with the human body only increases its usability in bio-applications. The main purpose of this research was to find the appropriate solvent system for poly(vinyl alcohol) and its printability. Solutions with the best properties were printed in pre-defined patterns and personally defined motifs and the printing conditions were optimized in order to obtain patterns with the best possible shape and resolution, which were analysed by optical microscopy.

Keywords: inkjet ink, poly(vinyl alcohol), printed patterns, viscosity, surface tension
\end{abstract}

Dandanes tehnologija tiskanja z brizganjem predstavlja eno najobetavnejših tehnik za nanašanje. Omogoča zelo natančen nanos funkcionalnih materialov na določeno mesto na podlago, je cenovno ugoden proces, še posebno pri zahtevnem posebnem načinu tiskanja. Poleg tega predstavlja odlično tehniko za kontroliran nanos polimernega materiala, še posebno raztopine polimera, zaradi nizke viskoznosti in boljše sposobnosti procesa. Zaradi vsestranske možnosti uporabe je bil izbran poli(vinil alkohol), poleg tega pa njegova kompatibilnost s človeškim telesom povečuje možnosti biouporabe. Glavni namen te raziskave je bil poiskati primeren sistem raztapljanja poli(vinil alkohola) s sposobnostjo za tiskanje. Raztopine z najboljšimi lastnostmi so bile uporabljene pri tiskanju določenih vzorcev in osebno opredeljenih motivov. Pogoji tiskanja so bili optimirani za doseganje vzorcev z največjo možno obliko in ločljivostjo, kar je bilo analizirano s svetlobno mikroskopijo.

Ključne besede: črnilo za brizganje, poli(vinil alkohol), tiskani vzorci, viskoznost, površinska napetost

\section{INTRODUCTION}

Inkjet printing (IJP) can be considered as an ideal manufacturing tool for the preparation of thin films or various shape patterns at required places. This technique is also suitable for patterning fragile as well as flexible substrates. In principle, the ink is converted into droplets that are ejected through nozzles and delivered onto the required place according to a predefined pattern controlled by a computer unit.

The droplets are supplied either continuously or on demand, which describes the two basic forms of IJP. The first type, continuous inkjet printing, is mainly used for coding; the stream of liquid is broken up into stream of droplets that are charged electrically. The required droplets are deflected during the flight through the deflection plate and delivered to the substrate; the non-deflected droplets are collected in a gutter, passed through the filter and reused (depending on the arrangement of the apparatus). On the other hand, the droplets are formed only when needed by a heater or piezo-element in dropon-demand (DOD) manner of inkjet printing, resulting in smaller drop size generation and higher placement accuracy in comparison with continuous IJP. ${ }^{1}$ Inkjet printing technology is used as a manufacturing tool in different industrial fields. There are numerous application examples of IJP, for instance, the technique is used to prepare organic light-emitting diodes (OLED) and polymer light-emitting diodes (PLED); printed electronics including sensors, solar cell, circuits; rapid prototyping; life science application including enzyme-based sensors, tissue engineering; and the other application such as flexible displays, magnetic and memory applications, and thin-film transistors. ${ }^{2-4}$ Moreover, the potential of IJP was successfully demonstrated in biological and pharmaceutical applications, as in ${ }^{1,5}$.

The IJP can be considered for a relative simple process, if all requirements are fulfilled. The requirements can be divided into four groups, namely: ink materials, substrate properties, droplet formation and the printing algorithm. Each element plays an important role in the whole printing system. The viscosity, surface tension and particles size represent the ink material group; for substrate, the crucial parameters are wettability, surface 


\section{MATERIALI IN TEHNOLOGIJE/MATERIALS AND TECHNOLOGY (1967-2017) - 50 LET/50 YEARS}

\section{P. ŠULY et al.: POLY(VINYL ALCOHOL): FORMULATION OF A POLYMER INK FOR THE PATTERNING OF SUBSTRATES ...}

energy and surface structure. Other properties are related to printing conditions, such as as drop generation, platform, and algorithm. These parameters include the type of used actuator, droplet size, printing procedure and others. ${ }^{6}$

In a polymer system the viscosity of the solutions or dilute solutions is defined by polymer concentration. In general, the viscosity of the solution increases with increasing content of the polymer at the same temperature, and opposite, the viscosity decreases with increasing temperature independently on the polymer concentration. A similar effect of temperature can be observed for the surface tension, but in this case, the overall change of surface tension is not as significant as in the case of the viscosity. Surface tension influences both the drop formation during the flight from nozzle to substrate and the wettability of printed substrate.

The shapes and quality of the printed patterns or motives depend on the required resolution and other parameters. N. Perinka et al. ${ }^{7}$ investigated the quality and morphology of printed motives using different print-head volumes, substrate temperatures, and firing voltages. They observed that each parameter significantly affects the final quality and uniformity of printed motives. The quantity of deposited material can be affected by firing voltage as well as the print-head volumes. The substrate temperature showed an important influence on the final morphology of the prepared layer.

IJP is ideal manufacturing tool for material deposition. There are a lot of articles focused on printing of dispersion and polymers used mainly in printed electronics; however, only few of them are focused on printability of water-soluble polymers (for example poly(vinyl alcohol), polyvinylpyrrolidone, polyacrylic acid, polyacrylamides and other).

In this work, the poly(vinyl alcohol) solutions were prepared in various polar solvents and their mixtures. The viscosity and surface tension of each solution were determined and adjusted so that the optimal values were achieved. The solutions with the best properties were then printed with a piezoelectric drop-on-demand material printer on a flexible substrate made from polyethylene terephthalate. Finally, the printed patterns were analysed microscopically. The main purpose of this research is finding the ideal solvent system for PVA and its printability.

\section{EXPERIMENTAL PART}

\subsection{Materials}

Two commercial poly(vinyl alcohols) (PVA) that represent water-soluble polymers, and Dimethyl sulphoxide (DMSO) for UV spectroscopy grade, $\geq 99.8 \%$ (GC), were purchased from Sigma-Aldrich. The main PVA characteristics are listed in Table 1. Distilled water was used as a major solvent. A food colorant was used for better visibility of printed layer onto polymer flexible substrate made from coated polyethylene terephthalate.
Table 1: The basic characteristics of poly(vinyl alcohols)

Tabela 1: Osnovne značilnosti poli(vinil alkoholov)

\begin{tabular}{|c|c|c|c|}
\hline Sample & PD $^{*}$ & DH $^{*}$ & $\mathrm{M}_{\mathrm{w}}{ }^{*}$ \\
\hline Mowiol $^{\circledR}$ 6-98 & 1000 & $98.0-98.8 \mathrm{~mol} \%$ & $\sim 47,000$ \\
\hline Mowiol $^{\circledR} 4-98$ & 600 & $98.0-98.8 \mathrm{~mol} \%$ & $\sim 27,000$ \\
\hline
\end{tabular}

* where PD is polymerization degree, $\mathrm{DH}$ is degree of hydrolysis, and $\mathrm{Mw}$ is weight average molecular weight

The pure PVA solutions at different concentrations were prepared by dissolving of granulated PVA in distilled water at $85 \pm 2{ }^{\circ} \mathrm{C}$ and continual stirring. Then, the different surfactants were added to solutions to decrease the surface tension. Later, the PVA was dissolved in a mixture of distilled water/DMSO in the volume ratio $2: 1$. DMSO has two roles in the used system, firstly as a co-solvent that has higher boiling point than water; secondly as a surfactant to decrease the surface tension of PVA solutions. All solutions were passed through a syringe filter (LUT Syringe Filters PTFE (Labicom s.r.o.) with pore size $0.24 \mu \mathrm{m}$ ) to eliminate the insoluble particles and other impurities.

\subsection{Methods}

The crucial parameters of each inkjet ink are viscosity, surface tension and conductivity at the jetting conditions (temperature, shear rate and others). Therefore, the viscosity and surface tension (SFT) measurements were determined with the highest precision. The viscosity measurements of the prepared solutions were carried out using a capillary Ubbelohde viscometer, type $0 \mathrm{a}$ and Ia depending upon the solutions' compositions and the expected viscosity at laboratory temperature. The density was determined by pycnometers. The final dynamic viscosity was calculated from the determined kinetic viscosity. The surface tension was carried out using a force tensiometer K100 from KRÜSS (GmbH Germany) using the plate method (also called the Wilhelmy plate method). In this assessment, the plate is oriented perpendicular to the interface, and the force exerted on it is measured.

Solution with suitable properties were filled into cartridges (type: piezo-driven jetting device with integrated reservoir and heater) and printed by Dimatix Materials Printer DMP-2800 series (Fujifilm Dimatix) on the coated PET foil. The printed patterns were analysed with an optical microscope LEICA DVM2500 Digital Camera (Leica Microsystems).

\section{RESULTS AND DISCUSSION}

\subsection{Polymer-solvent system}

Poly(vinyl alcohol) is a synthetic polymer that contains polar -OH side groups attached to the main carbon backbone. These polar groups prefer an interaction with the other group of the same affinity. In the other words, polar polymer is more soluble in polar solvents 
and conversely. Therefore, PVA is often dissolved in polar solvents such as water, dimethyl sulphoxide, ethylene glycol, and primary alcohols and others. It can also be expected that water will be the dominant solvent in all cases.

The properties of PVA, such as solubility, solvent resistance, flexibility, crystallinity, and viscosity, are affected mainly by its degree of hydrolysis (DH) and polymerization degree (DP). A higher dissolving temperature is necessary for more hydrolysed PVA. Similar behaviour occurred in the case of the comparison of two PVA with same degree of hydrolysis, but different DP. Moreover, these parameters also affect the viscosity of the solutions. The higher viscosity is observed for PVA with a higher DP or molecular weight and concentration due to presence of long chains that enhance the formation intra- and inter-hydrogen bonds. ${ }^{8,9}$

The first problem is dissolving the temperature associated with almost fully hydrolysed PVA used in this work because; the dissolving process is performed around $85^{\circ} \mathrm{C}$, at which the water evaporation process has begun. Therefore, the dissolving was carried out using a beaker covered by watch glass and a Petri dish; this arrangement was also helpful to maintain a stable dissolving temperature. This problem could be also partially solved by using any co-solvent with a higher boiling point, whereby a higher boiling point of the solvent mixture will be achieved. The high dissolving temperature also avoids using the commonly primary alcohols as a separate solvent because their boiling point does not exceed $100{ }^{\circ} \mathrm{C}$; for illustration, the following boiling points are noted, methanol $\sim 65{ }^{\circ} \mathrm{C}$, ethanol $\sim 78{ }^{\circ} \mathrm{C}$ and propan-1-ol $\sim 97{ }^{\circ} \mathrm{C} .{ }^{10}$ But, they could be used as surfactants due to their miscibility with water and low surface tension.

Finally, the PVA 6-98 was dissolved in pure water and water with the addition of ethanol. Ethanol was added to the solution after cooling to ambient temperature in various mass fractions. The PVA $4-98$ was dissolved in pure water and in a mixture of water/dimethyl sulphoxide (volume ratio $2: 1$ ). It represents a good ratio between the DMSO consumption and the needed value of SFT for the solution. The selected ratio was chosen after SFT measurements of mixtures water/DMSO in different ratios $(1: 1,2: 1,3: 1$ and $4: 1)$ without any polymer content.

\subsection{Viscosity and surface tension}

The basic characteristics of the solutions are listed and discussed in this section. However, the reasons for the used methods must be clarified. There are two main groups for the classification of fluids according their viscosity behaviour with respect to shear rate; Newtonian and non-Newtonian that involves pseudo-plastic (shearthinning) and dilatant (shear-thickening) fluids. The viscosity is independent over whole range of shear rate for the Newtonian. In contrast, the viscosity is changed within the shear rate in the case of non-Newtonian fluids. The change of viscosity according to the shear rate is typical for polymer solutions and the polymer concentration has an important role. ${ }^{11}$

If the print-head nozzle is considered as a long capillary with a small diameter, then an apparent shear rate could be calculated using the following Equation (1):

$$
\dot{\gamma}_{A}=\frac{4 \cdot \dot{Q}}{\pi \cdot R^{3}}
$$

Where $\dot{Q}$ is the volumetric flow rate $(\dot{Q}=S \cdot v), R$ is the capillary radius, $S$ is the nozzle area, and $v$ is the velocity of the droplets (detected by drop-watcher camera). In the results, the apparent shear rate must by corrected to the true shear rate (using Rabinowitz correction), but the value of the shear rate is above $1 \times 10^{5} \mathrm{~s}^{-1}$ in IJP. ${ }^{12}$

There are many studies in which the prepared inkjet inks are characterized by simple methods, for example, by a rolling balls AMVn viscometer ${ }^{13}$, a Brookfield viscometer ${ }^{14}$, or by changing the geometry of conventional rheometers. H. Dakhil and A. Wierschem ${ }^{15}$ reported the possibility to measure low viscosities at high shear rate by modification of a gap width in a commercial rotational rheometer. L. Pan and P. E. Arratia ${ }^{16}$ presented a PDMS-based microfluidic rheometer that can be used for the measurement of fluids with a Reynolds number $(R e)$ below 1 , and in range of shear rates up to $10^{4} \mathrm{~s}^{-1}$.

The $R e$ number is defined as the relative importance of the inertia forces to viscous forces:

$$
\operatorname{Re}=\frac{\rho \cdot v \cdot L}{\eta}
$$

Where $\rho$ and $\eta$ are the solution density and viscosity, $v$ is the mean fluid velocity and $L$ is a characteristic length scale. ${ }^{16}$ In our case, we consider $L$ as the nozzle diameter and $v$ as the droplet velocity during jetting.

Based on the observed data that are listed later, the calculated values of the prepared solution according to Equation (2) will be in the range 18.5-102.2, 22.0-39.7, 35.4-98.5, and 14.4-40.3 for aqueous PVA 6-98, PVA 6-98+ethanol, aqueous PVA 4-98, and PVA 4-98 in a water/DMSO mixture, respectively. These values of the Reynolds number correspond to a laminar flow for all the prepared solutions inside of the nozzle.

The most important dynamic parameters of inkjet inks are viscosity and surface tension. The measurements of viscosity and SFT have been performed by static methods due to both being impossible to measure at a high shear rate and the basic characterisation of the prepared solution for scientific purposes. However, based on the above-mentioned references, the obtained results hold up even for such high shear rate systems as IJP and the data can be successfully used in ink-formulation development. Tables $\mathbf{2}$ to $\mathbf{5}$ show the density, dynamic viscosity and surface tension of the prepared PVA solutions in different solvent systems at the laboratory tem- 
perature. The dynamic viscosity, $\eta$, values were calculated by using following Equation (3):

$$
\eta=\rho \cdot v
$$

Table 2: Density, dynamic viscosity and surface tension of PVA 6-98 aqueous solutions

Tabela 2: Gostota, dinamična viskoznost in površinska napetost vodne raztopine PVA 6-98

\begin{tabular}{|c|c|c|c|}
\hline $\begin{array}{c}\text { Concentration of } \\
\text { PVA 6-98 } \\
\text { solutions }(w / \%)\end{array}$ & $\begin{array}{c}\text { Density } \\
\left(\mathrm{kg} \cdot \mathrm{m}^{-3}\right)\end{array}$ & $\begin{array}{c}\text { Dynamic } \\
\text { viscosity }\left(10^{-3}\right. \\
\mathrm{Pa} \cdot \mathrm{s})\end{array}$ & $\begin{array}{c}\text { Surface } \\
\text { tension } \\
\left(10^{-3} \mathrm{~N} \cdot \mathrm{m}^{-1}\right)\end{array}$ \\
\hline 0.5 & 998 & 1.26 & 55.2 \\
\hline 1.5 & 1001 & 2.06 & 55.8 \\
\hline 2 & 1018 & 2.31 & 53.5 \\
\hline 2.5 & 1003 & 3.14 & 50.9 \\
\hline 3.5 & 1021 & 4.28 & 55.7 \\
\hline 5 & 1058 & 7.35 & 53.9 \\
\hline
\end{tabular}

Table 3: Density, dynamic viscosity and surface tension of PVA 6-98 aqueous solutions with ethanol

Tabela 3: Gostota, dinamična viskoznost in površinska napetost PVA 6-98 vodne raztopine $\mathrm{z}$ alkoholom

\begin{tabular}{|c|c|c|c|c|c|}
\hline $\begin{array}{c}\text { Origin PVA } \\
6-98 \text { conc. } \\
(w / \%)\end{array}$ & $\begin{array}{c}\text { Content } \\
\text { of } \\
\text { ethanol } \\
(w / \%)\end{array}$ & $\begin{array}{c}\text { New } \\
\text { conc. } \\
(w / \%)\end{array}$ & $\begin{array}{c}\text { Density } \\
\left(\mathrm{kg} \cdot \mathrm{m}^{-3}\right)\end{array}$ & $\begin{array}{c}\text { Dynamic } \\
\text { viscosity } \\
\left(10^{-3}\right. \\
\mathrm{Pa} \cdot \mathrm{s})\end{array}$ & $\begin{array}{c}\text { Surface } \\
\text { tension } \\
\left(10^{-3}\right. \\
\left.\mathrm{N} \cdot \mathrm{m}^{-1}\right)\end{array}$ \\
\hline 2.5 & 7.9 & 2.32 & 1007 & 3.27 & 48.2 \\
\hline 2.5 & 11.8 & 2.24 & 1003 & 3.46 & 46.0 \\
\hline 2.5 & 15.8 & 2.16 & 998 & 3.95 & 43.8 \\
\hline 3.5 & 11.8 & 3.13 & 1004 & 5.41 & 47.2 \\
\hline 3.5 & 15.8 & 3.02 & 1000 & 5.57 & 44.6 \\
\hline 3.5 & 19.7 & 2.92 & 995 & 5.83 & 41.1 \\
\hline
\end{tabular}

Table 4: Density, dynamic viscosity and surface tension of PVA 4-98 aqueous solutions

Tabela 4: Gostota, dinamična viskoznost in površinska napetost vodne raztopine PVA 4-98

\begin{tabular}{|c|c|c|c|}
\hline $\begin{array}{c}\text { Concentration of } \\
\text { PVA 4-98 } \\
\text { solutions }(w / \%)\end{array}$ & $\begin{array}{c}\text { Density } \\
\left(\mathrm{kg} \cdot \mathrm{m}^{-3}\right)\end{array}$ & $\begin{array}{c}\text { Dynamic } \\
\text { viscosity } \\
\left(10^{-3} \mathrm{~Pa} \cdot \mathrm{s}\right)\end{array}$ & $\begin{array}{c}\text { Surface } \\
\text { tension } \\
\left(10^{-3} \mathrm{~N} \cdot \mathrm{m}^{-1}\right)\end{array}$ \\
\hline 1 & 1016 & 1.33 & 60.0 \\
\hline 1.5 & 1017 & 1.67 & 58.8 \\
\hline 2 & 1018 & 1.97 & 61.1 \\
\hline 2.5 & 1020 & 2.43 & 59.4 \\
\hline 3 & 1021 & 2.64 & 60.2 \\
\hline 4 & 1023 & 3.73 & 60.7 \\
\hline
\end{tabular}

Table 5: Density, dynamic viscosity and surface tension of PVA 4-98 solutions in water/DMSO mixture

Tabela 5: Gostota, dinamična viskoznost in površinska napetost raztopine PVA 4-98 v mešanici voda/DMSO

\begin{tabular}{|c|c|c|c|}
\hline $\begin{array}{c}\text { Concentration of } \\
\text { PVA 4-98 } \\
\text { solutions }(w / \%)\end{array}$ & $\begin{array}{c}\text { Density } \\
\left(\mathrm{kg} \cdot \mathrm{m}^{-3}\right)\end{array}$ & $\begin{array}{c}\text { Dynamic } \\
\text { viscosity } \\
\left(10^{-3} \mathrm{~Pa} \cdot \mathrm{s}\right)\end{array}$ & $\begin{array}{c}\text { Surface } \\
\text { tension } \\
\left(10^{-3} \mathrm{~N} \cdot \mathrm{m}^{-1}\right)\end{array}$ \\
\hline 1 & 1069 & 3.42 & 53.8 \\
\hline 1.5 & 1069 & 3.98 & 52.8 \\
\hline 2 & 1071 & 5.19 & 53.8 \\
\hline 2.5 & 1070 & 5.66 & 56.7 \\
\hline 3 & 1073 & 7.25 & 56.3 \\
\hline 4 & 1072 & 9.61 & 56.4 \\
\hline
\end{tabular}

where $v$ is kinematic viscosity and $\rho$ is the density of solutions.

As can be seen, at the higher polymer concentration the higher viscosity was observed for both cases of PVA aqueous solutions, as for PVA 6-98 as for PVA 4-98. However, the PVA 6-98 aqueous solutions show higher viscosity values in comparison with the second one. This difference is caused by the higher polymerization degree (higher molecular weight), in which the presence of long chains enhances the formation of intra- and inter-hydrogen bonding, as were discussed previously and notified in ${ }^{8,9}$.

Similar behaviour was also observed for the surface tension. The SFT could be considered as a constant in both cases, because the SFT oscillates around the mean values $53 \mathrm{mN} \cdot \mathrm{m}^{-1}$ for PVA $6-98$ and $60 \mathrm{mN} \cdot \mathrm{m}^{-1}$ for PVA 4-98, respectively. Although small differences are seen, no upward or downward trend was recorded.

There are recommended values of viscosity and SFT for inkjet inks enabling the preparation of functional layers (or patterns) by the used material printer. The values for viscosity are in range of $10-12 \mathrm{mPa} \cdot \mathrm{s}$, and $28-42 \mathrm{mN} \cdot \mathrm{m}^{-1}$ for the surface tension, of course, at a certain jetting temperature. ${ }^{17}$ The obtained values of the SFT were higher than the recommended limits, thus, the SFT was decreased by using miscible additives. The available surfactant Triton X-100 and BYK-348 were added at the beginning, but decreasing of SFT was not observed. Moreover, Triton X-100 precipitated in the PVA solution. Therefore, the SFT was decreased by using the co-solvent. The different mass fraction of ethanol was added to PVA 6-98 solutions; the new concentration of solutions was calculated by using following Equation (4):

$$
w_{1} \cdot M_{1}+w_{2} \cdot M_{2}=w_{3} \cdot\left(M_{1}+M_{2}\right)
$$

where $w_{\mathrm{x}}$ is the weight fraction of polymer in solution and $M_{\mathrm{x}}$ is the weight of solution.

As can be seen, the addition of ethanol resulted in a small increase of the solution viscosity and lowers the SFT (Table 3). The effect of ethanol content on density, viscosity, and surface tension of binary water+ethanol mixtures at different temperature was investigated in ${ }^{18}$. They determined a limit for the mole fraction of ethanol at around 0.3; up to this limit the viscosity and density of mixture water + ethanol increase significantly, they reached maximum values at the mentioned value, and then decrease up to characteristic values for pure ethanol. For SFT, the simple downward trend was observed without any anomaly or unexpected deflections.

In short, the addition of $20 \%$ of mass fractions of ethanol taken on the mass of solution, (corresponding to $\sim 0.08$ mole fraction of ethanol), resulted in a decrease of SFT from $55 \mathrm{mN} \cdot \mathrm{m}^{-1}$ to $41 \mathrm{mN} \cdot \mathrm{m}^{-1}$ and an increase of viscosity from $4 \mathrm{mPa} \cdot \mathrm{s}$ to $6 \mathrm{mPa} \cdot \mathrm{s}$. A similar effect was observed for each other solution with a defined amount of ethanol. 


\section{MATERIALI IN TEHNOLOGIJE/MATERIALS AND TECHNOLOGY (1967-2017) - 50 LET/50 YEARS}

\section{P. ŠULY et al.: POLY(VINYL ALCOHOL): FORMULATION OF A POLYMER INK FOR THE PATTERNING OF SUBSTRATES ..}

DMSO was chosen as a co-solvent for PVA 4-98. The DMSO, polar solvent with higher boiling point than water, was a mixture with water at certain ratio before the dissolving process. In comparison with pure PVA 4-98 aqueous solutions, the solutions show lower surface tension, but higher density and viscosity at the same concentration of polymer (Table 4 and 5). The density was slightly increased (about 1.05 times), but the viscosity was increased by 3 times. The mean value of SFT decreased by $5 \mathrm{mN} \cdot \mathrm{m}^{-1}$ from $60 \mathrm{mN} \cdot \mathrm{m}^{-1}$ to $55 \mathrm{mN} \cdot \mathrm{m}^{-1}$. The mean value of SFT of the PVA 4-98 solutions is similar to the mean SFT value of PVA 6-98 aqueous solution. The viscosities of PVA 4-98 solutions prepared in water/DMSO are nearer to the recommended ink properties than other ones.

\subsection{Printing process}

The solutions showed the best properties from each polymer-solvent system were printed on flexible PET foil. There was also proposed a pulse waveform that consists of several stages that are defined by the slew rate, duration, and magnitude of pulse voltage. A uniform droplet velocity was achieved by adjusting the voltage at each nozzle. Figure 1 and Figure 2 show the droplets formation and ejection from the nozzle. As can be seen, the droplets velocity (about $6 \mathrm{~m} \cdot \mathrm{s}^{-1}$ ) was very similar in both cases. The mixture with ethanol did not show a significant long-tail formation in comparison with the next one. This long-tails disappeared several microseconds later during the airborne stage.

The printing of the PVA 6-98 aqueous solution at any concentration was impossible, probably due to the high DP and its effects. The same results were obtained in the case of the PVA 6-98 solution containing ethanol after printing several lines. Approximately a half of cartridge volume was consumed before clogging the nozzles that could be associated with the content of ethanol because of its low boiling point. Also, the relatively high temperatures of both cartridge and substrate $\left(33{ }^{\circ} \mathrm{C}\right.$ and $45{ }^{\circ} \mathrm{C}$, respectively) support the evaporation process that occurs before the printing process itself. The cleaning cycles were performed more often than for PVA 4-98 in

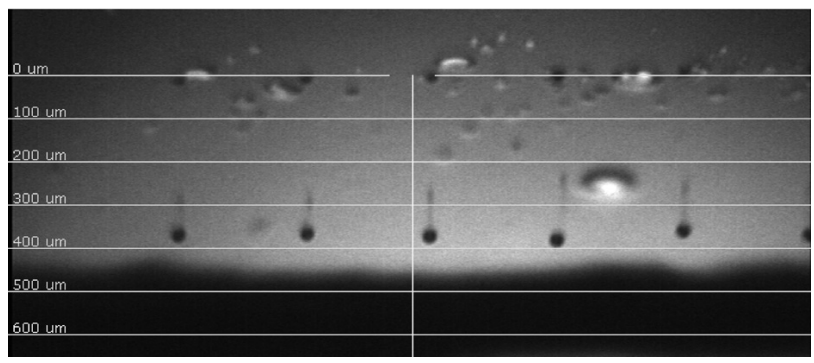

Figure 1: Droplets generation and their velocity, PVA concentration $2.5 \%$ of mass fractions in water with ethanol $(15.8 \%$ of mass fractions), firing voltage $28-32 \mathrm{~V}$, temperature of cartridge $33{ }^{\circ} \mathrm{C}$

Slika 1: Nastajanje kapljic in njihova hitrost, koncentracija PVA 2,5\% masnega deleža v vodi z etanolom ( $15,8 \%$ masnega deleža), napetost pri brizganju $28 \sim 32 \mathrm{~V}$, temperatura kartuše $33{ }^{\circ} \mathrm{C}$

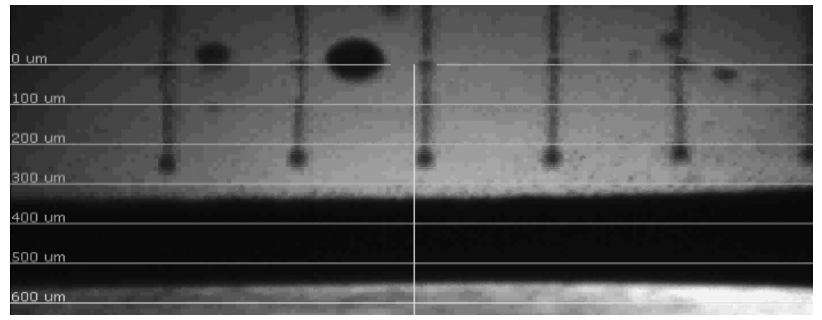

Figure 2: Droplets generation and their velocity, PVA concentration $2.5 \%$ of mass fractions in water/DMSO mixture, firing voltage $33 \mathrm{~V}$, temperature of cartridge $33{ }^{\circ} \mathrm{C}$

Slika 2: Nastajanje kapljic in njihova hitrost, koncentracija PVA 2,5 \% masnega deleža v mešanici voda/DMSO, napetost pri brizganju $33 \mathrm{~V}$, temperatura kartuše $33{ }^{\circ} \mathrm{C}$

mixture water/DMSO. A similar effect was also obtained for the PVA 4-98 aqueous solution.

The four basic groups of requirements important for ink formulation that have been mentioned in theory (materials - ink properties, substrate properties, droplet formation and the printing algorithm) are important; however, this work is focused on the preparation of an appropriate formula of polymer ink for specific substrate (coated PET foil). Thus, the modification of the substrate surface and the properties were not considered. Also, the printing algorithm (waveform) and its subgroups were used in the same way in all experiments once they had been optimized for the preparation of all the patterns. The last important group (droplet generation) was important, because the voltage waveform was prepared and applied for all solutions. Moreover, the uniform droplet velocity was reached by modification of the voltage for the needed nozzles. This voltage was different for each prepared polymer-solvent system.

\subsection{Analysis of printed patterns}

Well-defined patterns were printed after optimization of the printing conditions. The patterns include predefined and personally proposed patterns (single dots or

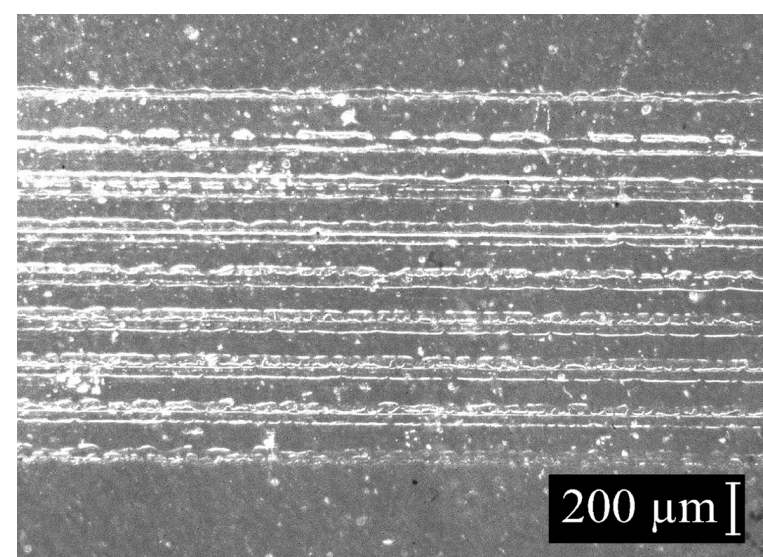

Figure 3: Magnified area of rectangle-shape pattern prepared from PVA 6-98 solution with $15.8 \%$ of mass fractions of ethanol

Slika 3: Povečano področje štirioglate oblike, pripravljene z raztopino s 15,8 \% masnim deležem PVA 6-98 v etanolu 
P. ŠULY et al.: POLY(VINYL ALCOHOL): FORMULATION OF A POLYMER INK FOR THE PATTERNING OF SUBSTRATES ...
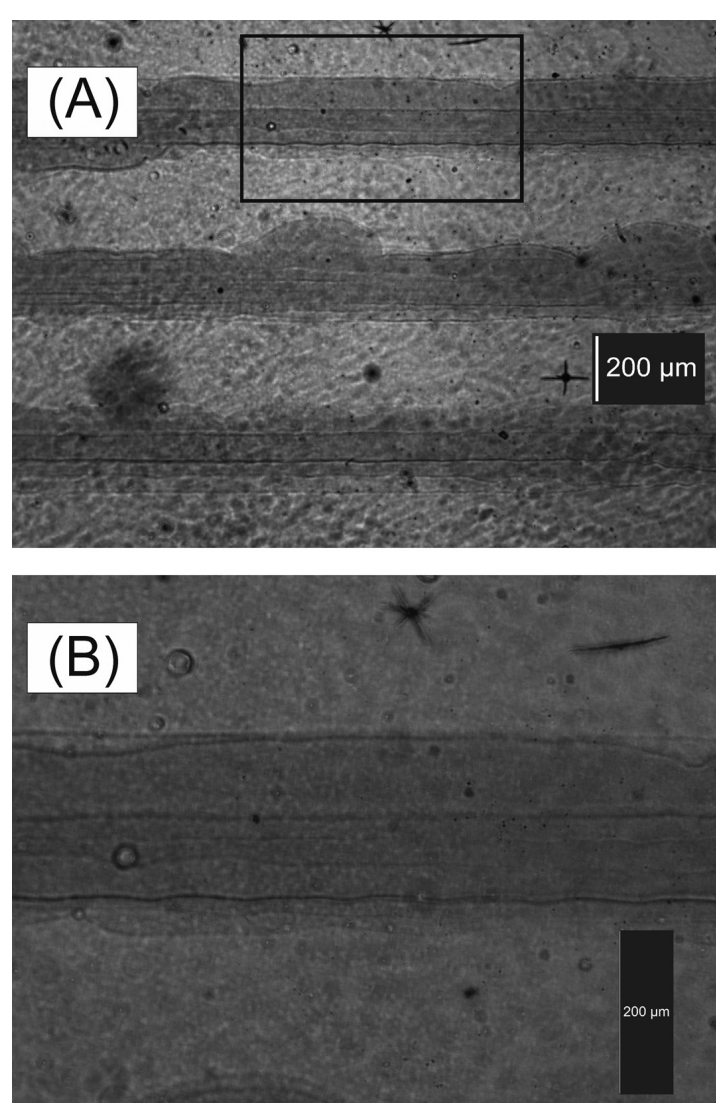

Figure 4: The set of lines of $3 \%$ of mass fractions of aqueous polymer solution PVA 4-98, magnified: a) 40 times, and b) 100 times, respectively

Slika 4: Množica linij s $3 \%$ masnega deleža raztopine polimera PVA 4-98, povečano: a) $40 \times$ in b) $100 \times$

dots array, rectangle-shape pattern with variation in resolution, and other motives). In this work, only fractions of prepared patterns are shown. Firstly, the simple rectangular-shape pattern was printed from the PVA 6-98 solution with the addition of ethanol. The pattern is shown in Figure 3. As can be seen, the pattern is not uniform; there are places where the particular printed lines affected each other (the left top corner), and in contrast, there are places where the solution ink is either missing or exists in an insufficient amount (the right bottom corner).

Depending on the observed results, the solution of PVA 4-98 was used to prepare a single-lines pattern. Based on the obtained results, the polymers with lower molecular weight are more suitable for the IJP process in comparison with a polymer with a high DP. This proposal can be supported by the following series of pictures. Figure 4 shows the printed lines of PVA aqueous solution with a lower DP. As can be seen, the edges of printed lines are not smooth, moreover, the bulging effect was observed in a random part of the lines. It suggested that the energy of the prepared ink was sufficient for drop formation, but the delay time was insufficient to eliminate this instability effect (bulging). The widths of the printed layers are about $200 \mu \mathrm{m}$. The food colorant
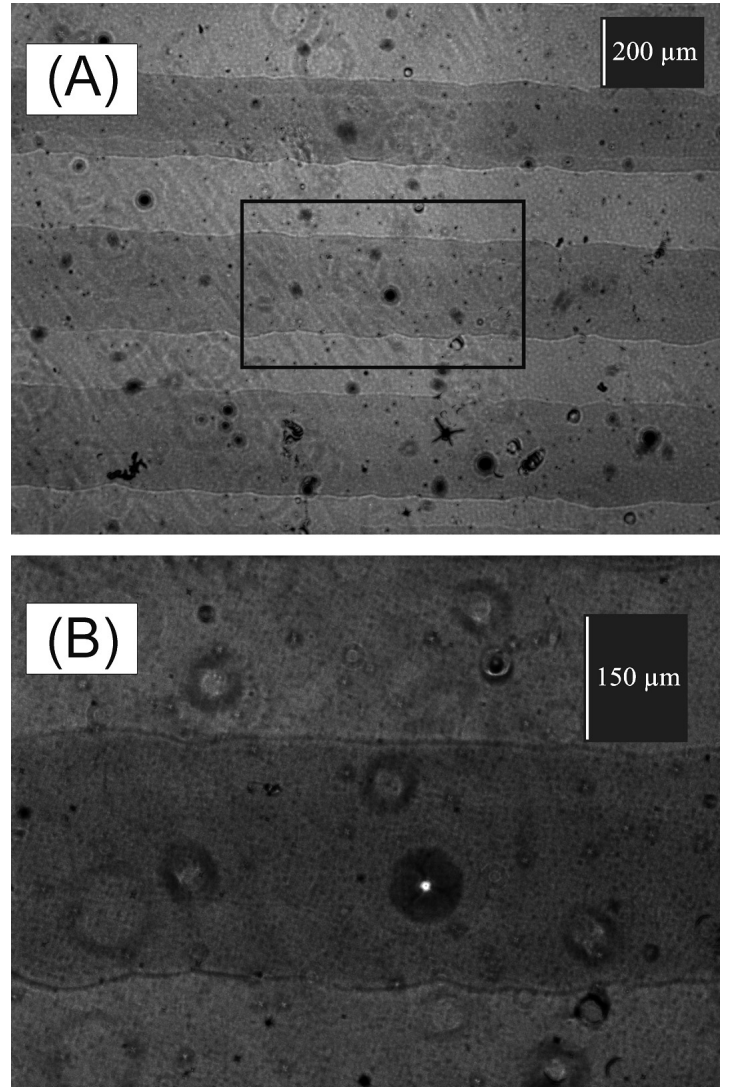

Figure 5: The set of lines of $2.5 \%$ of mass fractions of polymer solution PVA 4-98 in water/DMSO mixture, magnified: a) 40 times, and b) 100 times, respectively

Slika 5: Množica linij z 2,5 \% masnega deleža raztopine polimera PVA 4-98 v mešanici voda/DMSO, povečano: a) $40 \times$ in b) $100 \times$

was added to the solution to improve the visibility of the patterns (the amount of colorant was $0.5 \%$ of the mass fractions given to the amount of solution). It was found that the addition of colorant up to $1 \%$ of mass fractions has no influence on the structure of the printed patterns;

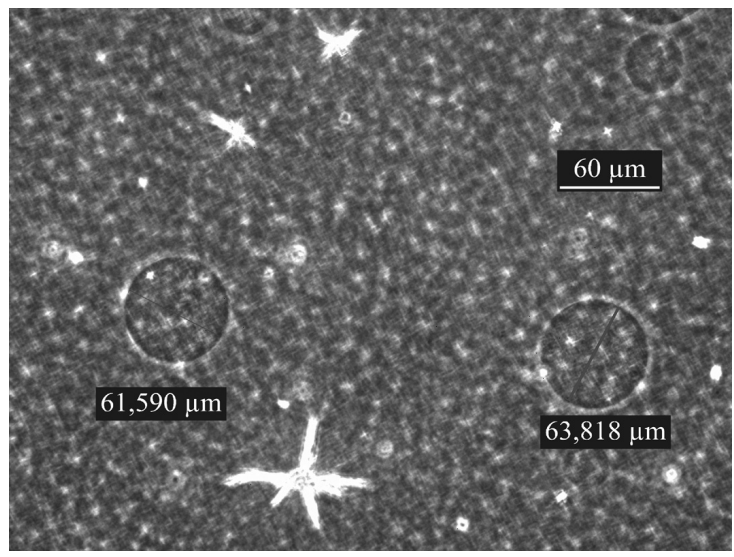

Figure 6: Single droplets prepared from $2.5 \%$ of mass fractions of polymer solution PVA 4-98 in water/DMSO mixture, magnified 200 times, $254 \mu \mathrm{m}$ drop spacing

Slika 6: Posamezne kapljice pripravljene iz 2,5 \% masnega deleža polimera PVA 4-98 v mešanici voda/DMSO, povečano $200 \times$, razdalja med kapljicama $254 \mu \mathrm{m}$ 
however, the larger amount of colorant together with the pattern's resolution can lead to the formation of crystalline structures. Tube-like shape structures were randomly situated on the surfaces of the patterns with a diameter in the range of $0.5 \mu \mathrm{m}$ up to $5 \mu \mathrm{m}$. The formation of the crystalline structure also depends on the drying condition.

The same pattern was also prepared from solution of PVA 4-98 in a water/DMSO mixture (Figure 5). The patterns are smoother, with good visible edges. The width of these lines is about $250 \mu \mathrm{m}$ and larger, which could be caused by the better wettability of the substrate by ink with a lower surface tension. Additionally, the last mentioned ink was used to prepare patterns based on single drops at accurate positions. The drop lines or drop arrays were prepared at various drop spacings. The results are shown in Figure 6. The distance between two neighbouring droplets is $254 \mu \mathrm{m}$. The droplet diameter is in the range 60-65 $\mu \mathrm{m}$. The droplets show an almost perfect circular shape, but their height is uneven. This effect could be controlled by adjusting the evaporation profile. In general, the effect is more visible at higher temperatures of the substrate..$^{7,19}$

\section{CONCLUSION}

Several solutions of PVA 6-98 and PVA 4-98 were prepared to find the optimal composition formula for the preparation of a polymer inkjet ink. The viscosity and surface tension were determined. The PVA 6-98 aqueous solutions were not suitable for the printing process at any polymer concentration. Next, the defined amount of ethanol was added to the solutions to decrease their surface tensions. This effect was observed, but ethanol probably caused the clogging of the print head nozzles because of its vapours at printing temperatures. The PVA 4-98 with a lower molecular weight was used in the next series of experiments. The pure PVA 4-98 aqueous solution at a certain concentration shows suitable properties for IJP processing. Several patterns were prepared, but the formation of the droplet and their jetting velocity were not uniform during the whole printing process, which led to the preparation of less accurate patterns. The best results were obtained for solutions of PVA 4-98 prepared in a water/DMSO $(2: 1 \mathrm{v} / \mathrm{v})$ solvent mixture. The prepared ink showed the best properties for the preparation of single drop patterns as well as other patterns such as grid, lines, rectangles, and other. The preparation of water-resistant patterns from PVA will be the goal of future work as well as the preparation of more sophisticated patterns. From a practical point of view, let us note that the results could extend the potential of PVA based formulations in the biological and medical sciences.

\section{Acknowledgements}

This work was supported by the Ministry of Education, Youth and Sports of the Czech Republic - Program NPU I (LO1504). We also acknowledge the support of the Internal Grant Agency of Tomas Bata University in Zlín (number: IGA/CPS/2015/006).

\section{REFERENCES}

${ }^{1}$ J. Li, F. Rossignol, J. Macdonald, Inkjet printing for biosensor fabrication: combining chemistry and technology for advanced manufacturing, Lab Chip, 15 (2015) 12, 2538-2558, doi:10.1039/ C5LC00235D

${ }^{2}$ A. Hudd, Inkjet Printing Technologies, The Chemistry of Inkjet Inks, S. Magdassi (Ed.), Singapore, World Scientific Publishing, 2010, 3-18

${ }^{3}$ B. Derby, Inkjet printing of functional and structural materials: fluid property requirements, feature stability, and resolution, Annual Review of Materials Research, 40 (2010) 1, 395-414, doi:10.1146/ annurev-matsci-070909-104502

${ }^{4}$ M. Singh, H. M. Haverinen, P. Dhagat, G. E. Jabbour, Inkjet printing-process and its applications, Advanced Materials, 22 (2010) 6, 673-685, doi:10.1002/adma.200901141

${ }^{5}$ Q. Zheng, J. Lu, H. Chen, L. Huang, J. Cai, and Z. Xu, Application of inkjet printing technique for biological material delivery and antimicrobial assays, Analytical Biochemistry, 410 (2011) 2, 171-176. doi:10.1016/j.ab.2010.10.024

${ }^{6}$ C.-T. Chen, Inkjet Printing of Microcomponents: Theory, Design, Characteristics and Applications, Features of Liquid Crystal Display Materials and Processes, N. V. Kamanina, (Ed.), Rijeka, Croatia, InTech, 2011, 43-60

${ }^{7}$ N. Perinka, C. H. Kim, M. Kaplanova, Y. Bonnassieux, Preparation and Characterization of Thin Conductive Polymer Films on the base of PEDOT:PSS by Ink-Jet Printing, Physics Procedia, 44 (2013), 120-129, doi:10.1016/j.phpro.2013.04.016

${ }^{8}$ J. Tao: Effects of Molecular Weight and Solution Concentration on Electrospinning of PVA. M.S. thesis, Mechanical Engineering Department, Worcester Polytechnic Institute, Worcester, MA, 2003 http://www.wpi.edu/Pubs/ETD/Available/etd-0613103-130015/unres tricted/jtao.pdf, 20.6.2015

${ }^{9}$ H. J. Endres, A. Siebert-Raths, Engineering Biopolymers: Markets, Manufacturing, Properties and Applications, Carl Hanser Verlag, Munich, 2011, 149-224

${ }^{10}$ J. Vohlídal, A. Julák, K. Štulík, Chemické a analytické tabulky, Praha: Grada Publishing, 1999, 177, 276, 369

${ }^{11}$ T. Sochi, Flow of non-newtonian fluids in porous media, Journal of Polymer Science Part B: Polymer Physics, 48 (2010) 23, 2437-2767, doi:10.1002/polb.22144

${ }^{12}$ X. Wang, W. W. Carr, D. G. Bucknall, J. F. Morris, High-shear-rate capillary viscometer for inkjet inks, Review of Scientific Instruments, 81 (2010) 6, 065106-, doi:10.1063/1.3449478

${ }^{13}$ C. A. Lamont, T. M. Eggenhuisen, M. J. J. Coenen, T. W.L. Slaats, R. Andriessen, P. Groen, Tuning the viscosity of halogen free bulk heterojunction inks for inkjet printed organic solar cells, Organic Electronics, 17 (2015), 107-114, doi:10.1016/j.orgel.2014.10.052

${ }^{14} \mathrm{X}$. Nie, H. Wang, J. Zou, Inkjet printing of silver citrate conductive ink on PET substrate, Applied Surface Science, 261 (2012), 554-560, doi:10.1016/j.apsusc.2012.08.054

${ }^{15}$ H. Dakhil, A. Wierschem, Measuring low viscosities and high shear rates with a rotational rheometer in a thin-gap parallel-disk configuration, Applied Rheology, 24 (2014) 6, 63795-, doi:10.3933/ ApplRheol-24-63795

${ }^{16}$ L. Pan, P. E. Arratia, A high-shear, low Reynolds number microfluidic rheometer, Microfluidics and Nanofluidics, 14 (2013) 5, 885-894, doi:10.1007/s10404-012-1124-2 
MATERIALI IN TEHNOLOGIJE/MATERIALS AND TECHNOLOGY (1967-2017) - 50 LET/50 YEARS

P. ŠULY et al.: POLY(VINYL ALCOHOL): FORMULATION OF A POLYMER INK FOR THE PATTERNING OF SUBSTRATES ...

${ }^{17}$ FUJIFILM Dimatix 2010, Fujifilm Dimatix Materials Printer DMP-2800 series: User Manual, Document no. PM000040 Rev. 05, http://www.lilliu.co.uk/resources/DMP/DMP2800GuideVersion2.0. pdf, 20.6.2015

${ }^{18}$ I. S. Khattab, F. Bandarkar, M. A. A. Fakhree, A. Jouyban, Density, viscosity, and surface tension of water+ethanol mixtures from 293 to 323 K, Korean Journal of Chemical Engineering, 29 (2012) 6, 812-817, doi:10.1007/s11814-011-0239-6

${ }^{19}$ Y. H. Yun, J. D. Kim, B. K. Lee, Y. W. Cho, H. Y. Lee, Polymer inkjet printing: construction of three-dimensional structures at micro-scale by repeated lamination, Macromolecular Research, 17 (2009) 3, 197-202, doi:10.1007/BF03218679 